\title{
TRANSAKSI AFILIASI DAN CAPITAL INTENSITY MEMPENGARUHI EMITEN DALAM MENGHINDARI PAJAK
}

\author{
Memed Sueb \\ FEB Universitas Padjadjaran, Bandung \\ Memed.sueb@fe.unpad.ac.id
}

Diterima 9 Juni 2020

Disetujui 19 Juni 2020

\begin{abstract}
Target of tax for several last year show increase positive as need of fund on State Budget. But on the other hand of emiten which listing in stock exchange Indonesia always comply to efisiensy of tax as tax planning. That is way by this research expected to find solution about what was variable effect to emiten comply tax efisiensy. Target of population were emiten which stock exchange for 3 year periode 2015 until 2017. Purposive sampling was choose to find out research data. The research selected 54 emiten as sample for representative of emitens. Tax avoidance was measured by proxy effective tax rates; affiliated transaction was measured by liabilities transaction affiliated. Hyphotesis was examined by multiple regression dan decision that: 1) Transaction affiliated affect emiten Industry manufacturing sector listed in Indonesia Stock Exchange during period in 20152017 for comply tax avoidance. Emitens have indication often make transaction with group (affiliated) for tax avoidance; 2) Capital intensity not affect emiten manufacturing sector listed in Indonesia Stock Exchange during period in 2015-2017 for comply tax avoidance. Emitens listed in Bursa Efek Indonesia higest invested on fixed asset not objective for tax avoidance but to support operating activity inclined rise.
\end{abstract}

\section{Keywords: Affiliated Transaction, Capital Intensity, Tax Avoidance,}

\section{PENDAHULUAN}

Dalam rangka melaksanakan jalannya pembangunan, pemerintah memerlukan dana yang tidak sedikit, oleh karenanya pemerintah harus mencari berbagai sumber pendanaan. Salah satu penerimaan Negara diantaranya adalah pajak, sebagai salah satu produk politik yang diatur dengan undang-undang. Ini yang menjadi ciri khas dalam pemungutan pajak yang harus diatur berdasarkan undang-undang disertai dengan ketentuan turunannya sampai kepada Surat Edaran Dirjen Pajak. Hal tersebut sesuai dengan teori di dalam azas pemungutan yang menegaskan bahwa pemungutan pajak tidak boleh dilaksanakan secara sembarangan memungut melainkan harus didasarkan pada undang-undang yang berlaku. Pajak sebagai hasil kompromi antara pemerintah dengan rakyatnya yang diwakili oleh anggota DPR mempunyai kekuatan mengikat untuk dilaksanakan. Artinya jika RUU yang diajukan oleh pihak eksekutif ke pihak legislatif lalu RUU tersebut disetujui dan menjadi Undang-undang maka semestinya para wajib pajak harus dapat melaksanakan UU Pajak tersebut karena sudah menyetujuinya.

Sampai saat ini pajak masih punya peran penting dalam penerimaan Negara. Oleh karena itu ketika para calon presiden berkampanye di depan masyarakat menjanjikan akan 
memakmurkan dan mensejahterakan rakyatnya. Ucapan ini tidak hanya berlaku untuk Negara tertentu tapi berlaku untuk semua Negara agar rakyatnya tertarik terhadap calon presiden tersebut. Namun demikian untuk mencapai Negara yang makmur sejahtera berkeadilan bukan hal yang mudah tapi diperlukan kerja keras dan tidak sedikit menguras pengorbanan. Agar tercapai semua cita-cita untuk mensejahterakan rakyat perlu adanya penerimaan Negara yang memadai yaitu dari pajak yang sampai saat ini masih menjadi tumpuan penerimaan Negara. Hal tersebut senada dengan pendapat yang disampaikan oleh peneliti sebelumnya (Cahyadi Putra \& Merkusiwati, 2016) yang mengatakan bahwa negara dapat maju berkembang dalam mensejahterakan rakyat demi masa depannya sebagai cermin kemampuan Negara dalam mengelola penerimaan pendapatan yang bersumber dari pajak.

Target pajak dalam beberapa tahun terakhir menunjukkan kemajuan yang positif sejalan kebutuhan dana yang ada dalam APBN. Menteri Keuangan yang paling bertanggungjawab dalam pencapaian penerimaan pajak yang harus kerja keras memutar otak bagaimana caraanya agar target pajak setiap tahun tercapai. Ketercapaian penerimaan pajak menunjukkan bahwa anggaran yang sudah disajikan dalam APBN harus dapat dipenuhi. Menteri keuangan dalam jumpa pers mengenai penerimaan pajak tahun 2017 dicapai $91 \%$ dari target APBN perubahan tahun 2017. Capaian tersebut termasuk paling tinggi dibandingkan dengan target tahun sebelumnya pada tahun 2015; 2016; masing-masing 83,3\% dan 83,5 Informasi yang disampaikan oleh Menteri Keuangan tersebut memberikan gambaran bahwa penerimaan pajak sangat penting dalam rangka memenuhi pencapaian APBN.

Berdasarkan pengalaman empiris dalam beberapa tahun terakhir ini peranan penerimaan perpajakan sangat dominan untuk menyelamatkan APBN (Hutagaol, 2006). Oleh karena itu penerimaan pajak (tax revenue management) merupakan suatu keharusan agar kontribusi pada APBN dapat berlangsung secara terus menerus (the sustainability of tax revenues contributin on the State Budget). Uraian tersebut di atas mendorong penulis mengadakan penelitian untuk mengetahui praktik para emiten dalam menghindari pajak. Ketika pemerintah sedang gencar meningkatkan penerimaan pajak, pada saat yang sama perusahaan (emiten) selalu berusaha melakukan pembayaran pajak secara efisien baik secara legal maupun ilegal.

Salah satu cara para emiten sebagai bentuk perlawanan aktif dalam menghadapi pajak yaitu secara terus menerus berupaya menghindari pembayaran pajak yang tidak semestinya. Upaya tersebut dianggap sudah biasa dilakukan oleh para pengusaha (wajib pajak) diantaranya untuk menghindari dalam memenuhi beban pajaknya. Hal tersebut sesuai dengan pendapat yang disampaikan (Hanlon \& Heitzman, 2010) yang menyatakan bahwa belum ada definisi yang disepakati oleh semua pihak mengenai cara para wajib pajak dalam menghindari kewajiban pajak yang tidak semestinya, untuk itu definisi cara menghindari pajak masih berbeda-beda (different things to different people). Hal senada disampaikan pula oleh (Dyreng et al., 2008b) memberikan definisi lebih luas mengenai yang dimaksud dengan menghindari pajak, yaitu sebagai bentuk upaya dalam mengurangi kewajiban pajaknya oleh para pengusaha sepanjang dianggap legal. Goh et al., (2016) memberikan pendapatnya yang menyatakan bahwa tindakan yang dilakukan oleh para pengusaha untuk menghindari kewajibannya membayar pajak dapat membantu cash flow perusahaan.

Menghindari kewajiban untuk membayar beban pajak yang dilakukan oleh wajib pajak pada dasarnya adalah suatu usaha dalam mengurangi kewajiban pajaknya semaksimal 
mungkin yang bertujuan agar tidak mengganggu cash flow perusahaan pada batas koridor yang diperbolehkan ketentuan yang ada dalam suatu Negara berupa undang-undang. Dampak yang terjadi akibat dari tindakan perusahaan yang melakukan menghindari pajak akan mengurangi penerimaan Negara. Freire-Serén \& Martí (2013) berpendapat menghindari pajak oleh para pengusaha akan menghambat pertumbuhan ekonomi. Bentuk lain cara menghindari pembayaran pajak walaupun sudah keluar dari koridor yang diperbolehkan secara undang-undang perpajakan yaitu disebut tax evasion. Menurut Hutagaol (2006), Gunadi (2007) dan Zain (2007) fenomena di Indonesia para wajib pajak melakukan penghindaran pajak disebabkan oleh beberapa alasan: 1) ada peluang akibat belum diatur dalam undang-undang perpajakan; 2) perbuatannya akan diketahui relatif kecil; 3) manfaat yang diperoleh lebih besar dibanding dengan risikonya; 4) sanksi perpajakan tidak terlalu berat; 5) adanya perbedaan dalam pemberian sanksi terhadap wajib pajak; 6) adanya diskriminasi dalam pemberian sanksi hukum.

Cara meminimalkan kewajiban pajak agar pajak yang dibayar efisien dan cara ini sudah termasuk melakukan pelanggaran terhadap undang-undang pajak. Praktek seperti ini dianggap ilegal dan sangat berisiko untuk siapapun yang menjalankan tax evasion ini dapat dikenakan sanksi pidana pajak. Oleh karena itu aparatur pemerintah dalam hal ini petugas pajak tidak dapat bertindak untuk memberikan sanksi kepada para pengusaha yang mengurangi kewajiban pajaknya selama tidak ada peraturan yang dilanggar. Penelitian pajak termasuk topik yang selalu hangat dan menarik untuk diteliti, karena persoalan pajak akan terus menerus muncul sejalan dengan perkembangan peradaban manusia. Bahkan berkembangnya pajak baik yang menyangkut objek maupun objek pajak dikarenakan oleh adanya kasus yang muncul di masyarakat.

Penelitian ini termasuk explanatory research yaitu untuk menguji varibel $\mathrm{X}$ dan $\mathrm{Y}$ hipotesis testing dipilih sebagai cara untuk mengkaji mengenai transaksi terafiliasi dan meningkatnya jumlah investasi dalam aktiva tetap pada para emiten. Adapun obyek yang diteliti merupakan para emiten yang menjual sahamnya di pasar bursa dalam hal ini adalah Bursa Efek Indonesia. Penelitian dilakukan selama tiga periode pengamatan yang dimulai sejak tahun 2015 s/d 2017. Adapun luaran dari kajian ini adalah untuk mencari jawaban mengenai apakah transaksi afiliasi dan capital intensity mempengaruhi para emiten (perusahaan) dalam menghindari pajak. Untuk itu diharapkan hasilnya dapat memberikan masukan kepada para emiten agar dalam praktek menghindari pajak tidak melanggar undang-undang perpajakan; pembuat kebijakan fiskal didalam menghadapi perilaku para emitan dalam praktik penghindaran pajak. Disamping itu semoga bermanfaat juga bagi para pemerhati pajak dalam melakukan kajian di masa yang akan datang guna penyempurnaan dan pengkayaan keilmuan bidang pajak. Perbedaan penelitian ini dengan penelitian sebelumnya terletak pada variabel independen yaitu para emiten yang diindikasikan mempunyai transaksi afiliasi dan memiliki intensitas aset yang besar; sedangkan variabel independen peneliti sebelumnya adalah laba, hutang, ukuran perusahaan, akses politik, struktur kepemilikan, karakter eksekutif, dan intesitas aset.

\section{TINJAUAN PUSTAKA DAN HIPOTESIS PENELITIAN}

\subsection{Teori Agensi}

Penelitian ini didasarkan pada teori agensi yang sudah dikembangkan oleh Ross (1973); lalu para pendukung berikutnya (Jensen \& Meckling, 1976; Fama \& Jensen, 1983), 
yang mengatakan bahwa terdapat hubungan antara pemilik dengan pengelola, para pengelola berupaya perusahaan memperoleh laba agar aset para investor bertambah sebagai bentuk tanggungjawab atas pendelegasian yang diberikan oleh pemilik sebagai investor. Topik pajak sampai saat ini termasuk bahan kajian yang banyak peminat peneliti untuk menelitinya. Peneliti sebelumnya yang relevan dengan penelitian ini diantaranya adalah penelitian Gupta \& Newberry, (1997); Dyreng et al., (2008a); Fernández-Rodríguez \& Martínez-Arias (2012); dan Himmah \& Sedianingsih (2018). Banyak peminat untuk meneliti pajak dikarenakan pajak sangat populer dan termasuk bidang yang banyak diperhatikan masyarakat, karena paling bersentuhan langsung dengan kehidupan berupa harta dan penghasilan. Oleh karena itu para peneliti sebelumnya sudah banyak yang meneliti mengenai pajak, khususnya mengenai cara menghindari pembayaran pajak. Namun demikian menurut para ahli bahwa mengenai praktik transaksi afiliasi dan capital intensity banyak dilaksanakan oleh perusahaan besar dalam rangka perencanaan pajak.

Para wajib pajak selalu berusaha agar kewajiban pajaknya berkurang atau seefisien mungkin yaitu dengan cara penghematan pajak (tax saving). Hal tersebut sesuai dengan pendapat yang disampaikan oleh Zain (2007) yang mengatakan bahwa penghematan merupakan strategi oleh para pengusaha dalam memperkecil kewajiban pajaknya untuk yang diluar lingkup pemajakan, maksudnya adalah menghindari pembayaran beban pajak suatu usaha hampir sama seperti penghematan pajak cuma dengan cara mencari celah kelemahan di dalam peraturan pajak yang berlaku. Lebih lanjut Faisal (2016) berpendapat bahwa menghindari pajak dengan skema transaksi yang bertujuan untuk meminimalisasi kewajiban pajak dengan mengeksploitasi kekurang sempurnaan undang-undang perpajakan dengan tanpa melanggar hukum. Sehingga aparat direktorat jenderal pajak tidak dapat melakukan tindakan apapun.

Pada prinsipnya cara menghindari pajak sepanjang tidak menyalahi peraturan yang berlaku di Indonesia masih dapat ditolelir, karena termasuk strategi perencanaan pajak yang dapat dilakukan oleh wajib pajak dan sebagai bentuk dalam perlawanan aktif. Effective tax rates sering digunakan untuk mengukur penelitian mengenai para wajib pajak yang berusaha menghindari kewajiban membayar pajak. Frank et al., (2009) berpendapat bahwa Effective tax rates adalah sebagai gambaran adanya perbedaan antara laba fiskal dengan laba akuntansi (komersial). Selanjutnya, Hanlon \& Heitzman (2010) berdasarkan hasil penelitiannya berpendapat bahwa untuk menghitung effective tax rates (ETR) diperolah dengan cara membagi hutang pajak atau kewajiban pajak perusahaan dengan penghasilan kena pajak atau laba sebelum pajak. Begitu juga dalam penelitian ini untuk menghitung effective tax rate dihitung menggunakan cara yang sama yaitu total kewajiban dibagi dengan penghasilan sebelum kena pajak. Peneliti sebelumnya yang melakukan penelitian serupa diantaranya adalah Hanlon \& Heitzman (2010); Fernández-Rodríguez \& Martínez-Arias (2012); Freire-Serén \& Panadés i Martí (2013); Khomsatun \& Martani (2015); Goh et al., (2016); Irianto, Sudibyo \& Wafirli (2017);Holzmann (2018a); dan Anindyka, Dimas, Pratomo, Dudi, Kurnia (2018).

Berdasarkan cara tersebut dapat diketahui perbandingan kewajiban pajak yang ditimbulkan dari laba kena pajak (LKP) sesuai fiskus (undang-undang pajak), terhadap laba komersial mengikuti aturan Standar Akuntansi Keuangan (SAK) sehingga dapat diketahui besarnya persentase kewajiban pajak perusahaan yang sebenarnya terhadap laba akuntansi (komersial). Melalui ETR dapat diketahui perbandingan tarif pajak berdasarkan akuntansi 
(komersial) dengan tarif pajak yang ditetapkan peraturan perpajakan. Oleh karena itu dengan cara menghitung menggunakan effective tax rate dapat ditentukan jumlah kewajiban pajak yang harus dibayar sebagai strategi yang sudah umum dilakukan oleh para pengusaha dalam menghemat beban sebagai kewajiban yang harus dibayarnya.

Memperkecil atau kecilnya perhitungan effective tax rates yang terjadi dalam suatu perusahaan dapat mengindikasikan adanya para pengusaha (wajib pajak) menghindari pajak Gupta (1997). Pemerintah harus tanggap terhadap adanya gejala yang sering dilakukan oleh para pengusaha untuk selalu mensiasati untuk meningkatkan efisiensi dalam memenuhi kewajiban pajaknya. Tindakan yang dilakukan oleh para pengusaha tersebut dapat merugikan karena mengurangi potensi penerimaan Negara. Untuk itu dalam rangka menghindari maraknya para pengusaha untuk menghindari pajak yang berpotensi berkurangnya penerimaan Negara dari pajak. Langkah kongkrit yang harus dilakukan oleh Pemerintah dalam mengatasi para pengusaha yang termasuk kategori strategi dalam menghindari dari pajak yaitu dengan melakukan transfer pricing. Cara tersebut menurut Holzmann (2018b) sebagai bentuk transaksi yang dilakukan para pengusaha dengan penetapan harga tidak berdasarkan harga pasar. Berdasarkan hasil penelitiannya, Utama (2015) menambahkan bahwa transaksi yang mempunyai hubungan istimewa dapat merugikan juga untuk para pemegang saham minoritas.

Praktek transfer pricing menurut Maulana et al., (2018) adalah sebagai cara untuk menghindari pajak yang selama ini sering dilakukan oleh para wajib pajak. Hal tersebut dengan cara transfer pricing sering digunakan oleh para pengusaha untuk menggeser laba antar Negara dengan harapan agar pembayar pajak lebih efisien. Mencari tempat yang mempunyai tarif pajak yang kecil, lalu di Negara yang menerapkan pajak yang kecil tersebut dibuat labanya tinggi sebaliknya pada Negara yang menerapkan tarif pajaknya besar dibuat keuntungannya kecil bahkan dibuat rugi. Kondisi tersebut didukung oleh pendapatn Himmah \& Sedianingsih (2018) yang berpendapat bahwa para pengusaha membuat perusahaan pada beberapa Negara yang disebut multinasional sering digunakan untuk berbuat perencanaan pajak sebagai usaha menghindari kewajiban pajak yang harus dibayar.

Praktek transfer pricing sering diterapkan oleh para pengusaha yang membuka perusahaan pada berbagai Negara yaitu cara mendirikan dalam bentuk cabang; anak perusahaan; badan usaha tetap yang disebut perusahaan multi nasional. Lebih lanjut, Huda et al., (2017) berpendapat bahwa konsekuensi adanya transfer pricing untuk Pemerintah dapat mengurangi penerimaan potensi pajak, pada saat bermunculan perusahaan multinasional yang terindikasi memilih Negara yang mempunyai tarif pajak paling rendah. Dalam upaya meredam maraknya transaksi transfer pricing yang dapat mengurangi penerimaan Negara.

Pemerintah melalui Keputusan Ketua Bapepam dan Lembaga Keuangan No. 412/BL/2009 yang mengatur tentang Transaksi Afiliasi dan Benturan Kepentingan Transaksi tertentu. Berdasarkan peraturan tersebut sebagai upaya pemerintah untuk membendung praktek apapun yang dilakukan oleh para wajib pajak dapat berpontensi merugikan keuangan Negara. Diharapkan dengan adanya Advance Pricing Agreement (APA) untuk memecahkan praktik transfer pricing yang dapat diterima oleh semua pihak baik fiskus maupun wajib pajak. Padahal APA juga sering digunakan oleh para wajib pajak karena efektif digunakan untuk mengantisipasi rumitnya pemeriksaan transaksi transfer pricing. Hal tersebut sependapat dengan Taylor \& Richardson (2013) yang mengatakan 
bahwa pemerintah harus mempunyai aturan mengenai mekanisme transaksi yang terindikasi melakukan menghindari pajak.

\subsection{Hipotesis Penelitian}

\subsubsection{Pengaruh Transaksi Afiliasi Terhadap Penghindaran Pajak}

Para pengusaha di dalam menjalankan usahnya selalu berpikir mencari cara untuk meningkatkan efisiensi dalam berbagai aspek termasuk beban pajak. Cara berpikir tersebut tentunya sesuai dengan tujuan didirikannya adalah untuk mendapatkan laba yang besar dan maksimal. Sebagai implementasi cara berpikir tersebut yaitu dengan memperbanyak transaksi yang masih dalam satu group perusahaan yang terafiliasi. Praktek transaksi dengan perusahaan yang terafiliasi dengan harapan dapat melakukan tranfer pricing diantara sesama anggota group perusahaan dalam mengatur harga jual barang atau jasa.

Transaksi afiliasi ada hubungannya dengan teori agensi. Terjadinya konflik kepentingan antara pemilik perusahaan untuk mendapatkan laba yang tinggi agar diperoleh dividen yang besar. Di lain pihak pengelola perusahaan mengharapkan laba yang rendah agar membayar pajak juga kecil. Hal tersebut sependapat juga dengan Dyreng et al., (2008b) yang menyatakan bahwa konflik keagenan dapat diperluas adanya perbedaan kepentingan antar pemegang saham. Pemangku kepentingan mayoritas akan mencoba menyerap semua keuntungan perusahaan untuk meraup uang yang ada dalam perusahaan untuk memenuhi kepentingan diri sendiri, sebuah kegiatan yang dikenal dengan "tunneling". Kegiatan tunneling dilakukan terutama melalui hubungan bisnis diantara sesama perusahaan yang terafiliasi atau dalam group perusahaan yang sama. Tambunan et al., (2016) menyatakan bahwa thin capitalization yang dipraktekan oleh banyak perusahaan sangat berpotensi sebagai sarana melakukan transfer pricing yang akan mengurangi laba kena pajak.

Pada transaksi terafiliasi para pengusaha sering mempraktekan transaksi jual beli dalam penetapan harga yang biasanya tidak mencerminkan harga wajar karena harga ditetapkan untuk mendapatkan laba yang tinggi di negara yang menerapkan tarif pajakyang rendah dan laba yang rendah di negara yang mempunyai tarif pajak yang tinggi. Para pelaku bisnis tidak menerapkan kewajaran dan kelaziman atas barang yang dibeli ataupun yang dijual yang sesuai dengan harga pasar, melainkan lebih mengutamakan prinsip perencanaan pajak untuk pelaporan pajak.

Menurut Hanlon \& Heitzman (2010), wajib pajak dapat menghindari pajak dengan cara mengatur transaksi dengan pihak terkait, seperti melalui skema thin capitalization atau skema transfer pricing. Huda et al., (2017) berpendapat terutama praktik transfer pricing pada perusahaan multinasional ada upaya meminimalkan kinerja operasi dan mengoptimalkan cara menghindari pajak adalah lebih penting. Perusahaan yang tidak melakukan transaksi dengan arm's length dapat menyebabkan audit pajak atau investigasi oleh pihak berwenang (OECD, 2012). Global Transfer Pricing Survey oleh Ernst and Young pada tahun 2016 menunjukkan bahwa 75\% perusahaan mengindikasikan "manajemen risiko pajak" sebagai prioritas utama penetapan harga transfer mereka, naik dari hasil survey pacta tahun 2013 yaitu 66 persen, dan pada tahun 2007 dan 2010 yang hanya sebesar 50 persen (G, 2008).

Maraknya praktek transaski antar sesama anggota group perusahaan multinasional di Indonesia sering menimbulkan rekayasa transfer pricing, hal tersebut terutama pada perusahaan yang berstatus penanaman modal asing (PMA) dan cabang perusahaan asing di 
Indonesia yang berbentuk usaha tetap (BUT). Sebagian besar perusahaan tersebut bergerak di bidang industri manufaktur dan mempunyai kaitan internal yang cukup substansial dengan induk perusahaan atau afiliasinya di Negara lain. Menurut Gunadi (2007b) berdasarkan suatu studi di beberapa Negara yaitu: Amerika Serikat, Kanada, Inggris, Jerman, dan beberapa Negara Eropa Lainnya serta Jepang hasilnya pada tahun 1970-an sekitar lebih dari $75 \%$ perdagangan internasional Negara-Negara tersebut dilakukan antar perusahaan yang tergabung dalam kelompok perusahaan multinasional.

Wise et al., (2003) berpendapat bahwa perusahaan di Kanada para pengusaha memilih bertransaksi bisnisnya dengan perusahaan dalam satu kelompoknya sebagai upaya untuk meningkatkan efisiensi pajak dengan cara penetapan harga jual bukan dengan harga pasar. Gunadi (2007b) mengatakan pada umumnya perusahaan di Indonesia sering dimanfaatkan oleh perusahaan industri manufaktur untuk kelompok barang menengah (intermediate goods) juga bahan baku (raw materials) diantara kelompok mereka lalu hasil produksinya dijual lokal atau diekspor ke negara dunia ketiga yang masih dalam satu group usaha. Ini juga dapat berpotensi mengurangi penerimaan negara yang mengganggu pertumbuhan ekonomi suatu negara. Berdasarkan uraian tersebut diatas dibentuk hipotesis bahwa:

\section{$\mathrm{H}_{1}$ :Transaksi afiliasi mempengaruhi para emiten untuk menghindari pajak.}

\subsection{Pengaruh Capital Intensity Terhadap Penghindaran Pajak}

Perusahaan yang bersifat konglomerasi atau juga group perusahaan yang terdiri dari holding dan cabang. Holding company atau perusahaan induk dalam rangka perencanaan pajak dilakukan dengan cara menambah penghasilan dari bunga untuk perusahaan induk dan mengurangi laba kena pajak pada perusahaan anak. Perusahaan induk lebih suka meningkatkan pinjaman daripada menambahkan modalnya pada perusahaan anak. Melakukan kebijakan tersebut dengan maksud agar beban pajak di anak perusahaan membesar dan laba kena pajak mengecil.

Strategi yang dilakukan oleh para pengusaha tersebut mendapat dukungan dari Harrington \& Smith (2012) yang berpendapat bahwa pada umumnya untuk menghindari beban pajak memperbesar beban bunga agar laba kena pajak menjadi mengecil. Pendapat yang sama disampaikan oleh Khomsatun \& Martani (2015) yang mengemukakan bahwa praktek perusahaan yang dinamakan thinly capitalization karena perusahaan sering memperbesar utang berbasis bunga lalu yang berakibat jumlah modal menjadi kecil. Praktek tersebut bertujuan jika perusahaan induk setor modal akan mendapatkan dividen ketika perusahaan anak memperoleh laba. Namun dividen ini tidak dapat mengurangi laba kena pajak pada perusahaan anak akibatnya membayar pajak tidak efisien.

Cara treaty shopping sebagi bentuk lain yang sering juga dilakukan oleh para wajib pajak untuk menghindari pajaknya melalui treaty shopping para wajib pajak memanfaatkan fasilitas tax treaty suatu Negara pada Negara lain oleh perusahaan yang tidak berhak dan controlled foreign corporation/CFC (menahan laba di Negara tax haven untuk menunda pemajakan di Negara domisili). Perusahaan juga sering menerapkan Capital intensity ratio yaitu perbandingan jumah investasi dengan aktiva tetap. Perusahaan yang sengaja memperbesar capital intensity ratio yang besar pula agar beban depresiasi yang dapat mengurangi laba kena pajak juga besar, oleh karena itu sering dimanfaatkan oleh para wajib pajak dalam melaksanakan penghematan pajak karena beban depresiasi dapat mengurangi 
laba sebelum pajak.

Hal tersebut sesuai dengan pendapat peneliti Fernández-Rodríguez \& MartínezArias (2012) yang berpendapat bahwa investasi dalam bentuk aktiva tetap pada perusahaan berpotensi mengurangi kewajiban untuk membayar pajak karena adanya beban penyusutan aktiva tetap sebagai pengurang laba kena pajak. Selanjutnya, Hanlon \& Heitzman (2010) mengungkapkan bahwa perusahaan dapat mendapatkan insentif pajak dengan memanfaatkan menghindari pajak selain dari utang, yaitu depresiasi, investment tax credits, dan net operating loss carry forwads. Oleh karena itu dengan meningkatkan komposisi investasi dalam aktiva tetap akan berdampak terhadap beban penyusutan aktiva tetap, sehingga effective tax rate yang dimiliki perusahaan akan semakin rendah yang menjadi indikasi melakukan penghematan pajak.

Ada beberapa hasil penelitian mengenai berbagai bentuk penghematan dalam pembayaran pajak oleh para wajib pajak, yaitu peneliti yang ditemukan oleh Gupta (1997) hasil temuannya mengatakan bahwa yang dapat mempengaruhi negatif terhadap effective tax rate adalah capital intensity; sedangkan yang berpengaruh negative adalah inventory intensity; dan research and development intensity tidak memberikan pengaruh terhadap effective tax rates. Temuan peneliti berikutnya adalah Richardson \& Lanis (2007) menunjukkan hasil bahwa agresivitas pajak secara positif dipengaruhi oleh capital intensity. Penelitian lainnya oleh Sugiyarti (2017); dan Anindyka, Dimas, Pratomo, Dudi, Kurnia (2018); berpendapat bahwa perusahaan memperbesar aktiva tetap agar beban penyusutan besar dan akan mengurangi laba kena pajak.

Namun demikian tidak selamanya bahwa tingginya perusahaan berinvestasi pada aktiva tetap bertujuan mengurangi beban pajak. Hal tersebut sesuai dengan hasil penelitian Yuliana \& Wahyudi (2018) berpendapat bahwa aktivitas perusahaan berinvestasi dalam aktiva tetap untuk operasional perusahaan sebagai bentuk untuk meningkatkan laba. Perusahaan berinvestasi pada aktiva tetap karena tuntutan aktivita perusahaan yang meningkat yang dapat berimbas pada pencapaian laba yang meningkat juga. Hal senada juga disampaikan hasil penelitiannya Irianto, Sudibyo \& Wafirli (2017) mengatakan bahwa aktiva tetap yang dimilik perusahaan tidak memberikan gambaran yang cukup untuk menyatakan bahwa perusahaan tersebut melakukan efisiensi dalam pembayaran pajak. Berdasarkan uraian tersebut masih ada silang pendapat mengenai capital intensity ini. Namun demikian ada indikasi bahwa besarnya investasi dalam bentuk aktiva tetap berpengaruh positif terhadap para pengusaha untuk menghindari pajak. Berdasarkan uraian tersebut di atas dibentuk hipotesis bahwa:

\section{$\mathrm{H}_{2}$ : Capital intensity mempengaruhi para emiten untuk menghindari pajak.}

\section{METODOLOGI DAN ANALISA DATA}

Penelitian dilaksanakan pada bulan September sampai November tahun 2018 analisis data pada emiten yang menjual sahamnya di Bursa Efek Indonesia khusus emiten sektor manufaktur. Penelitian dilakukan selama tiga periode pengamatan yang dimulai sejak tahun 2015 s/d 2017.

Alasan memilih para emiten tersebut yang dijadikan objek penelitian adalah dengan pertimbangan bahwa sektor manufaktur termasuk pembayar pajak paling besar. Disamping itu perusahaan manfaktur juga dapat mewakili perusahaan lain karena mempunyai 
karakteristik proses bisnis yang lengkap dan ada indikasi cenderung lebih sering melakukan perencanaan pajak sebagai strategi untuk menghindari beban pajak. Metode deskriptif digunakan dalam penelitin ini. Populasi para emiten sektor manufaktur yang menjual sahamnya di pasar bursa dalam hal ini adalah Bursa Efek Indonesia tahun 2015 s/d 2017. Adapun yang memenuhi syarat untuk diteliti 18 emitan selama 3 tahun menjadi 54 pengamatan. Penentuan sampel berdasarkan teknik pemilihan sampel dengan pertimbangan yang sesuai dengan kehendak peneliti. Kriteria sampel:

1. Para emiten selama periode penelitian

2. Para emiten selama tahun 2015 - 2017 yang publikasi melalui internet

3. Para emiten yang dikendalikan

4. Para emiten yang menyajikan laporan tahunan bukan dalam valas

5. Para emiten yang tidak memiliki kompensasi rugi fiskal

6. Para emiten yang memiliki data sesuai dengan kebutuhan penelitian

7. Para emiten yang tidak memilik data ekstrim atau data outlier

Jumlah sampel yang terpilih disajikan pada Tabel 1

Tabel 1. Jumlah Sampel

\begin{tabular}{|l|l|c|}
\hline No. & \multicolumn{1}{|c|}{ Uraian } & $\mathrm{n}$ \\
\hline 1 & Emiten 2015-2017 & 144 \\
\hline 2 & Emiten 2015-2017 yang tidak lengkap & $(13)$ \\
\hline 3 & Emiten tidak mempublikasikan 2015-2017 melalui internet & $(4)$ \\
\hline 4 & Emiten memiliki net income negatif & $(20)$ \\
\hline 5 & Emiten yang tidak dikendalikan & $(23)$ \\
\hline 6 & Emiten yang menggunakan valas & $(6)$ \\
\hline 7 & Emiten yang tidak diperlukan & $(1)$ \\
\hline 8 & Emiten memiliki data outlier & 18 \\
\hline 9 & Jumlah & 3 \\
\hline 10 & Tahun & 54 \\
\hline 11 & Jumlah sampel dalam periode penelitian & \\
\hline
\end{tabular}

Sumber: Hasil olahan Peneliti 


\section{Definisi Operasional Variabel}

Variabel dependen adalah upaya menghindari pajak dinotasikan ETR.

Variabel:

$$
\mathrm{ETR}=\frac{\text { Beban PPh }}{\text { Laba sebelum kena pajak }}
$$

Adapun variabel independen atau variabel bebas $X_{1}$ yaitu transaksi afiliasi, dikatakan transaksi afiliasi apabila terpenuhinya salah satu dari kriteria: 1) Kepemilikan atau penyertaan modal paling rendah $25 \%$; 2) faktor penguasaan; Variabel transaksi afiliasi dilambangkan dengan UTA

$\mathrm{UTA}=\frac{\text { Total utang kepada afiliasi }}{\text { total utang perusahaan }}$

Variabel independen atau variabel $\mathrm{X}_{2}$ dilambangkan dengan CAPINT

CAPINT $=\frac{\text { Total aset tetap bersih }}{\text { jumlah aset }}$

Data dianalisis menggunakan persamaan regresi berganda yang sebelumnya diuji mengikuti persyaratan prsamaan regresi berganda. Data sekunder berupa pooled data kombinasi crosssectional yang saling melengkapi. Model matematis hubungan antar variabel adalah $\mathrm{ETR}=\alpha+\beta_{1} \mathrm{UTA}+\beta_{2} \mathrm{CAPINT}+\varepsilon$

\section{HASIL PENELITIAN DAN DISKUSI}

\subsection{Statistik Deskriptif}

Pada Tabel 2 disajikan analisis deskriptif

Tabel 2. Analisis Deskriptif

\begin{tabular}{|l|c|c|c|}
\hline \multicolumn{4}{|c|}{ Descriptive Statistics } \\
\hline Description & ETR & UTA & CAPINT \\
\hline Mean & 0,244232 & 0,127348 & 0,410936 \\
\hline Median & 0,252475 & 0,050990 & 0,423647 \\
\hline Maximum & 0,459420 & 0,777021 & 0,783978 \\
\hline Minimum & 0,024231 & 0,001621 & 0,148781 \\
\hline Std.Dev. & 0,083703 & 0,156100 & 0,167751 \\
\hline Observations & 54 & 54 & 54 \\
\hline
\end{tabular}

\subsection{Uji Asumsi Klasik}

\subsubsection{Uji Heterokedastisitas}

Uji Heterokedastisitas Bertujuan mengetahui apakah error konstan atau tidak. Model regresi penelitian untuk menguji heterokedastisitas menggunakan uji Glejser dengan bantuan 
software program EViews 8. Uji tersebut dalam rangka memperoleh probabilitas dari Obs*Rsquared.

Tabel 3. Uji Glejser

Uji Glejser

\begin{tabular}{llll}
\hline \hline F-statistic & 0,302715 & Prob. F(2,51) & 0,7401 \\
Obs*R-squared & 0,633522 & Prob. Chi-Square(2) & 0,7285 \\
Scaled explained SS & 0,844276 & Prob. Chi-Square(2) & 0,6556 \\
\hline
\end{tabular}

Berdasarkan Tabel 3 Terlihat bahwa hasil probabilitas Obs*R-square $(0,7285)>\alpha(0.05)$. Dengan demikian bahwa hal ini menunjukkan bahwa tidak terjadi heteroskedastisitas.

\subsubsection{Multikolinearitas}

Selanjutnya uji multikolinearitas untuk mendapatkan bukti bahwa antar variabel tidak memiliki hubungan atau antar variabel independen dalam model regresi panel.

\begin{tabular}{lccr} 
Uji Multikolinearitas & Tabel 4. Uji Multikolinearitas & \\
\hline \hline Variable & $\begin{array}{c}\text { Coefficient } \\
\text { Variance }\end{array}$ & $\begin{array}{c}\text { Uncentered } \\
\text { VIF }\end{array}$ & $\begin{array}{r}\text { Centered } \\
\text { VIF }\end{array}$ \\
\hline \hline & & & NA \\
C & 0,001048 & 7,827506 & 1,000606 \\
UTA & 0,005597 & 1,678219 & 1,000073 \\
CAPINT & 0,004846 & 7,114652 & \\
\hline \hline
\end{tabular}

Berdasarkan hasil pengujian EViews 8 pada Tabel 4 ternyata memberikan bukti bahwa model regresi yang digunakan dalam penelitian ini tidak terdapat multikolinearitas, ditunjukan karena nilai Centered VIF berada dibawah 10 untuk setiap variabel yang ada dalam penelitian ini.

\subsubsection{Uji Autokorelasi}

Hasil uji autokorelasi adalah:

Uji Autokorelasi

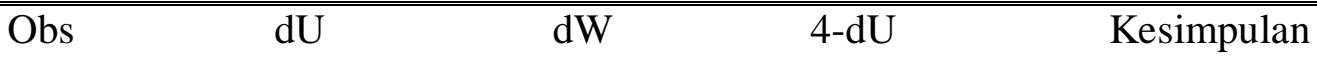

$\begin{array}{llll}54 & 1,59829 & 2,137336 & 2,40171\end{array}$

Berdasarkan Tabel 5 nilai dU diperoleh dari lampiran Tabel Durbin-Watson dengan tingkat kesalahan sebesar 5\% dengan jumlah data 54 untuk jumlah variabel bebas (k) 2. Berdasarkan hasil pengujian diketahui jika nilai dW yang diperoleh untuk model tersebut berada diantara nilai dU dan 4-dU. Hasil tersebut menandakan model regresi yang digunakan sudah terbebas dari persoalan autokorelasi, oleh karena itu model tersebut memenuhi salah satu persyaratan menggunakan regresi. 


\subsection{Persamaan Regresi Berganda}

Berdasarkan pengolahan data menggunakan software EViews 8, diperoleh hasil pada Tabel 6 sebagai berikut

Tabel 6. Tabel Hasil Regresi Berganda

\begin{tabular}{|l|l|l|l|}
\hline \multirow{2}{*}{ Variabel Independen } & \multicolumn{2}{|c|}{ ETR } \\
\cline { 2 - 4 } & \multicolumn{1}{|c|}{ Coefficient } & t-Statistics & \multicolumn{1}{c|}{ Prob } \\
\hline C (Constant) & 0,240952 & 6,487530 & 0,0000 \\
\hline UTA & $-0,031527$ & $-0,390001$ & 0,0009 \\
\hline CAPINT & 0,017752 & 0,221390 & 0,4257 \\
\hline R-squared & & & 0,423369 \\
\hline Adjusted R-squared & & & 0,101133 \\
\cline { 1 - 2 } & & & 6,142178 \\
\hline F-statistic & & 0,000008 \\
\hline
\end{tabular}

Berdasarkan hasil pengolahan program EViews 8

$\mathrm{ETR}=0,240952-0,031527 \mathrm{UTA}+0,017752 \mathrm{CAPINT}$

Bahwa:

ETR = penghindaran pajak

$\alpha \quad=$ konstanta

$\beta \quad=$ koefisien regresi

UTA $\quad=$ transaksi afiliasi sebagai variabel independen

CAPINT = capital intensity sebagai variabel independen

\section{DISKUSI HASIL PENELITIAN}

\subsection{Pengaruh Transaksi Afiliasi Terhadap Para Emiten Untuk Menghindari Pajak}

Hasil pengujian hipotesis bahwa nilai koefisien variabel transaksi afiliasi $-0,031527$ pada tingkat signifikansi 0,0009 . Tingkat signifikansi yang dimiliki variabel transaksi afiliasi lebih kecil dari 0.05 mengindikasikan mempengaruhi secara signifikan antara transaksi afiliasi terhadap para emiten untuk menghindari pajak (ETR). Dengan demikian dapat diambil kaidah keputusannya agar dapat menerima $\mathrm{H}_{1}$ dan menolak $\mathrm{H}_{0}$ yang dengan demikian bahwa transaksi afiliasi atau UTA memiliki pengaruh yang signifikan terhadap para emiten dalam menghindari pajak pada perusahaan yang diteliti untuk emiten manufaktur yang terdaftar di BEl tahun 20152017. Koefisien minus menunjukkan arah negatif artinya ada hubungan yang terbalik antara transaksi afiliasi dengan nilai effective tax rates. Jika para emiten di Bursa Indonesia semakin kecil nilai effective tax rates menunjukkan bahwa para emiten diindikasikan menghindari pajak. Hal tersebut sesuai dengan hasil penelitian Gupta \& Newberry (1997b) yang menyatakan bahwa rendahnya effective tax rates yang terjadi pada perusahaan dapat mengindikasikan 
adanya penghindaran pajak. Artinya semakin tinggi para emitan melakukan transaksi dengan perusahaan yang terafiliasi akan memiliki nilai effective tax rates yang menandakan semakin tinggi pula para emiten untuk menghindari pajak.

Hasil kajian penulis ini sesuai pula dengan hasil penelitan Handayani \& Arfan (2014) yang menyatakan bahwa transaksi afiliasi berpengaruh positif untuk menghindari pajak. Hal tersebut dikarenakan bahwa praktik transaksi afiliasi didorong oleh perusahaan di Indonesia pada umumnya dimiliki oleh pemegang saham yang terkonsentrasi. Kondisi ini bahkan bukan hanya terjadi di Indonesia tetapi berlaku juga pada beberapa negara di Asia untuk perusahaan terbuka pemegang sahamnya terkonsentrasi. Dampak kurang baiknya bentuk struktur kepemilikan seperti ini berpotensi terjadinya kerugian pada pemegang saham yang jumlahnya lebih kecil (pemegang saham minoritas). Hal tersebut sesuai dengan hasil penelitian Utama (2015) yang yang menghasilkan temuannya bahwa praktik yang terjadi oleh pemegang saham mayoritas tersebut sering melakukan transaksi dengan perusahaan yang terafiliasi. Akibatnya transaksi yang terjadi diantara sesama group perusahaan dapat diatur dalam penetapan harga jual yang biasanya tidak meggunakan harga pasar.

Kondisi yang terjadi pada perusahaan dengan komposisi kepemilikan yang terpusat, biasanya pemegang saham dominan dapat menguasai dan mendominasi dan bahkan dapat mengambil alih kekayaan pemegang saham minoritas dengan berbagai cara. Sehingga para pemegang saham mayoritas dapat memperoleh uang tambahan dengan menjual aset, barang, atau layanan kepada perusahaan melalui transaksi afiliasi dengan harga di atas harga pasar; dapat memperoleh pinjaman dengan persyaratan yang sesuai dengan keinginan yang menguntungkan perusahaan; dapat mentransfer aset antar perusahaan yang berada di bawah kendalinya; dan lebih buruk lagi, dapat mencairkan kepemilikan yang dapat merugikan kepentingan minoritas.

Hipotesis yang menyatakan bahwa transaksi afiliasi mempengaruhi para emiten dalam menghindari pajak secara statistik maupun secara keilmuan dalam bidang perpajakan terbukti. Dengan demikian bahwa hipotesis yang diajukan dalam penelitian ini dinyatakan terbukti dapat diterima. Artinya semakin banyak para emiten melakukan praktik transaksi dengan perusahaan terafiliasi dalam kelompok group yang sama maka mengindikasikan bahwa semakin besar kemungkinan para emiten untuk menghindari kewajiban pajaknya. Hal tersebut terbukti yang ditunjukkan oleh adanya penurunan (semakin kecilnya) nilai effective tax rates. Keuntungan perusahaan melakukan transaksi dengan pihak yang terafiliasi adalah dapat mengatur harga jual sesuai dengan kondisi yang diinginkan oleh para wajib pajak. Namun dilihat dari aspek perpajakan konsekwensinya seluruh transaksi yang dilakukan oleh wajib pajak ini dianggap tidak sah karena harga jual dan harga beli tidak wajar mengikuti harga pasar yang tidak sesai dengan peraturan yang berlaku di Indonesia.

\subsubsection{Pengaruh Capital Intensity Terhadap Para Emiten Untuk Menghindari Pajak}

Berdasarkan hasil pengujian hipotesis menunjukkan nilai koefisien variabel transaksi afiliasi adalah 0,017752 pada tingkat signifikansi 0,4257. Tingkat signifikansi dengan variabel capital intensity dikarenakan lebih besar dari 0,05 dengan demikian kaidah keputusannya menolak $\mathrm{H}_{2}$ dan menerima $\mathrm{H}_{0}$. Hal ini menunjukkan bahwa capital intensity tidak mempengaruhi para emiten manufaktur yang terdaftar di BEl tahun 2015-2017 untuk menghindari pajak. Artinya semakin tinggi capital intensity belum tentu berdampak pada semakin tingginya para emiten menghindari pajak. Hasil kajian ini sesuai juga dengan pendapat para peneliti sebelumnya yaitu Lestari \& Sugiharto (2007) berpendapat bahwa ada beberapa kemungkinan yang menyebabkan hipotesis $\mathrm{H}_{2}$ tidak didukung oleh peneliti sebelumnya. Puspita \& Febrianti (2018) berpendapat bahwa besarnya aktiva tetap yang dimiliki perusahan yang 
mengakibatkan beban penyusutan juga menjadi besar tidak berpengaruh terhadap pengurangan pajak penghasilan perusahaan. Begitu juga hasil penelitian Putra \& Merkusiwati (2016) yang berpendapat bahwa perusahaan yang memiliki aktiva yang lebih dominan nilainya dibanding dengan aset lainnya ternyata tidak berindikasi melakukan menghindari pajak. Besarnya aktiva tetap dalam perusahaannya bertujuan untuk meningkatkan aktivitas operasi agar lebih optimal. Namun ada pula perusahaan lain memperbesar investasi pada aktiva tetap bertujuan mengefisienkan beban pajak. Ternyata berdasarkan kajian ini tidak selamanya perusahaan berinvestasi pada aktiva tetap dalam rangka menghidari pajak.

Ada beberapa alasan yang masuk akal dari hasil kajian ini. Kemungkinan pertama bahwa jumlah aktiva tetap yang dimiliki para emiten yang sahamnya dijual di Bursa Indonesia mempunyai nilai ekonomis yang besar namun umur ekonomisnya sudah melewati masa manfaat umur ekonomis menurut fiskal. Akibat dari kondisi tersebut aktiva tetap yang dimiliki para emiten sudah tidak ada lagi beban penyusutan yang dapat mengurangi laba kena pajak. Terdapatnya perbedaan peraturan mengenai umur ekonomis antara Standar Akuntansi Keuangan dengan aturan perpajakan mengakibatkan koreksi fiskal yang bersifat sementara (perbedaan waktu). Sehingga akibat adanya perbedaan umur ekonomi menurut akuntansi (komersial) lebih panjang dari umur ekonomi menurut fiskal beban penyusutan menurut akuntansi (komersial) tidak dapat mengurangi laba kena pajak.

Kemungkinan yang kedua adalah besarnya aktiva tetap yang ada dalam perusahaan bertujuan untuk meningkatkan kapasitas produksi agar lebih optimal yang akan berdampak terhadap peningkatan laba perusahaan sebagai akibat adanya penambahan aktiva tetap. Tingginya aktiva tetap ini akan menunjang aktivitas operasional perusahaan sehingga lebih optimal dan laba perusahaan juga bertambah. Oleh karena itu sekalipun beban penyusutan tinggi akan tetapi karena diimbangi dengan pendapatan operasional perusahaan lebih tinggi. Sehingga ketika menghitung laba kena pajak akan diperoleh hasil bahwa penghasilan kena akan jauh akan jauh lebih tinggi yang pada gilirannya akan kas yang dikeluarkan perusahaan juga besar. Investasi dalam aktiva tetap yang tepat akan lebih menguntungkan dibandingkan dengan melakukan efisiensi pajak dengan memanfaatkan beban penyusutan yang dapat mengurangi laba kena pajak dengan tidak mengganggu cash flow perusahaan. Oleh karena itu banyak cara yang dapat dilakukan perusahaan dalam rangka memenuhi kenginan share holder (pemegang saham).

\section{KETERBATASAN PENELITIAN, KESIMPULAN DAN SARAN 6.1 Keterbatasan Penelitian}

1 Variabel transaksi afiliasi proksi yang digunakan hanya terbatas menggunakan nilai related party transaction (RPT) dalam hal utang pihak berelasi.

2 Nilai Adjusted $\mathrm{R}^{2}$ dalam penelitian ini hanya 0,101133 atau $10,11 \%$ ada indikasi terdapat faktor lainnya diluar variabel yang diteliti yang mempengaruhi tidndakan penghindaran pajak

3 Penelitian hanya menggunakan perusahaan manufaktur sebagai sampel penelitian

4 Jumlah sampel yang digunakan hanya 54 emiten

\subsection{Kesimpulan}

1. Transaksi afiliasi mempengaruhi para emiten pada industry manufaktur yang terdaftar di Bursa Efek Indonesia pada periode 2015-2017 dalam menghindari pajak. Kondisi tersebut menunjukkan bahwa semakin tinggi para emiten melakukan transaksi dengan perusahaan terafiliasi maka akan semakin tinggi pula peluang para emiten untuk menghindari pajak. Karena harga transaksi yang dilakukan dengan pihak terafiliasi tidak 
didasarkan pada harga pasar tetapi didasarkan kepada kepentingan perusahaan yang bersangkutan. Sebaliknya semakin rendah transaski afiliasi menunjukkan bahwa semakin rendahnya penghndaran pajak

2. Capital intensity tidak mempengaruhi para emiten industry manufaktur yang terdaftar di Bursa Efek Indonesia pada periode 2015-2017 dalam menghindari pajak. Kondisi tersebut menunjukkan bahwa semakin tinggi capital insensity belum tentu berdampak pada semakin tingginya penghindaran pajak. Begitu juga semakin rendah capital intensity belum tentu akan mengakibatkan para emiten semakin rendah untuk menghindari pajak. Kondisi ini tergantung kepada keberadaan aktiva tetap di perusahaan. Jika umur ekonomis menurut akuntansi (komersial) lebih panjang dibandingkan dengan umur ekonomi secara fiskal akan mengakibatkan beban penyusutan menurut komersial (akuntansi) tidak dapat mengurangi laba kena pajak. Begitu juga jika aktiva tetap digunakan dalam operasional perusahaan yang mengakibatkan pendapatan perusahaan jauh lebih besar dibandingkan beban penysutan yang mengakibatkan laba kena pajak juga akan semakin besar pula.

\subsection{Saran}

1. Untuk Pemerintah harus meningkatkan pengawasan terhadap para pengusaha yang memiliki harga transfer diluar batas kewajaran atau arms' length dan memperketat regulasi yang berhubungan dengan transaski afiliasi yang berpotensi melakukan penghindaran pajak

2. Untuk Perusahaan walaupun menghindari pajak yang selama ini dianggap wajar dalam praktek bisnis dan tidak menyalahi peraturan yang ada, namun perusahaan agar lebih bijak dalam melakukan penghindaran pajak dengan tidak terlalu merugikan negara, sehingga kredibilitas perusahaan dapat terjaga.

3. Peneliti selanjutnya agar ditambah jumlah sampel dengan cara menambah periode pengamatan; variabel dapat ditambah yang diduga dapat digunakan sebagai alat menghindari pajak.

Implikasi dari hasil penelitian ini kepada pemerintah agar membuat aturan yang jelas atau mereformasi undang-undang perpajakan khususnya mengenai transaksi afiliasi karena masih banyak para wajib pajak yang memanfaatkan celah kelemahan peraturan perpajakan yang ada selama ini. Apabila ini dibiarkan terus akan mengakibatkan potensi penerimaan negara menjadi hilang. Implikasi buat para wajib pajak khususnya pelaku bisnis adalah sampai saat ini masih punya kesempatan untuk memanfaatkan celah-celah perpajakan (tax loophole) dengan cara melakukan transaksi bisnis dalam satu group yang terafiliasi. Para pelaku bisnis dapat mengefisienkan pembayaran pajak selama tidak melanggar aturan yang ada dapat diperbolehkan. 


\section{REFERENSI}

Anindyka, Dimas, Pratomo, Dudi, Kurnia. (2018). Pengaruh Leverage ( Dar ), Capital Intensity Dan Inventory Intensity Terhadap Tax Avoidance. E-Proceeding of Management :, 5(1), 713-719.

Cahyadi Putra, I., \& Merkusiwati, N. (2016). Pengaruh Komisaris Independen, Leverage, Size Dan Capital Intensity Ratio Pada Tax Avoidance. E-Jurnal Akuntansi, 17(1), 690-714.

Dyreng, S. D., Hanlon, M., \& Maydew, E. L. (2008a). Long-run corporate tax avoidance. Accounting Review. https://doi.org/10.2308/accr.2008.83.1.61

Dyreng, S. D., Hanlon, M., \& Maydew, E. L. (2008b). Long-Run Tax Avoidance Corporate. The Accounting Review.

Faisal, A. (2016). Karakteristik Eksekutif, Profitabilitas, Kepemilikan Institusional, Dan Ukuran Perusahaan Serta Dampak Terhadap Tax Avoidance. Universitas Muhammadiyah Yogyakarta.

Fama, E. F., \& Jensen, M. C. (1983). Agency Problems and Residual Claims. SSRN Electronic Journal, XXVI(June), 327-349. https://doi.org/10.2139/ssrn.94032

Fernández-Rodríguez, E., \& Martínez-Arias, A. (2012). Do business characteristics determine an effective tax rate? Chinese Economy. https://doi.org/10.2753/CES1097-1475450604

Frank, M. M., Lynch, L. J., \& Rego, S. O. (2009). Tax Reporting Aggressiveness and Its Relation to Aggressive Financial Reporting. Accounting Review. https://doi.org/10.2308/accr.2009.84.2.467

Freire-Serén, M. J., \& Panadés i Martí, J. (2013). Tax Avoidance, Human Capital Accumulation and Economic Growth. Economic Modelling, 30(1), 22-29. https://doi.org/10.1016/j.econmod.2012.08.021

G, Y. A. (2008). Ernst \& Young 's Global Transfer Pricing Survey - Transfer Pricing Documentation and Controversy Risk Management Practices. 1-2.

Goh, B. W., Lee, J., Lim, C. Y., \& Shevlin, T. (2016). The Effect of Corporate Tax Avoidance on The Cost of Equity. Accounting Review, 91(6), 1647-1670. https://doi.org/10.2308/accr-51432

Gunadi. (2007a). pajak internasional. lembaga penerbit fe ui.

Gunadi. (2007b). Pajak Internasional (Edition Revition). Lembaga Penerbit Fakultas Ekonomi Universitas Indonesia.

Gupta, S. (1997). A review of tax the variability in corporate effective tax rates evidence from longitudinal data. Accounting and Public Policy.

Gupta, S., \& Newberry, K. (1997a). Determinants of the variability in corporate Cffective Tax Rates: Evidence from Longitudinal Data. Journal of Accounting and Public Policy, 16(1), 1-34. https://doi.org/10.1016/S0278-4254(96)00055-5

Gupta, S., \& Newberry, K. (1997b). Determinants of The Variability in Corporate Effective Tax Rates: Evidence From Longitudinal Data. Journal of Accounting and Public Policy, 16(1), 1-34. https://doi.org/10.1016/S0278-4254(96)00055-5

Handayani, D., \& Arfan, T. (2014). Pengaruh Transaksi Perusahaan Afiliasi Terhadap Tarif Pajak Efektif. Jurnal Akuntansi Keuangan Dan Bisnis.

Hanlon, M., \& Heitzman, S. (2010). A review of tax research. In Journal of Accounting and Economics. https://doi.org/10.1016/j.jacceco.2010.09.002

Harrington, C., \& Smith, W. (2012). Tax avoidance and corporate capital structure. Journal of Finance and Accountancy, 11, 144-164.

Himmah, E. F., \& Sedianingsih. (2018). Determinant of Capital Structure on Multinationality Company in Indonesia. Jurnal Akuntansi Universitas Jember, 15(2), 1. 
https://doi.org/10.19184/jauj.v15i2.7252

Holzmann, C. (2018a). Transfer Pricing as Tax Avoidance Under Different Legislative Schemes. SSRN Electronic Journal, July. https://doi.org/10.2139/ssrn.3164103

Holzmann, C. (2018b). Transfer Pricing as Tax Avoidance Under Different Legislative Schemes. SSRN Electronic Journal. https://doi.org/10.2139/ssrn.3164103

Huda, M. K., Nugraheni, N., \& Kamarudin, K. (2017). The Problem of Transfer Pricing in Indonesia Taxation System. International Journal of Economics and Financial Issues.

Hutagaol, J. (2006). Kapita Selekta Perpajakan (First Edition). Salemba Empat.

Irianto, D. B. S., Sudibyo, Yudha Aryo\& Abim, Wafirli. (2017). The Influence of Profitability, Leverage, Firm Size and Capital Intensity Towards Tax Avoidance. International Journal of Accounting and Taxation. https://doi.org/10.15640/ijat.v5n2a3

Jensen, M. C., \& Meckling, W. H. (1976). Theory Of The Firm: Managerial Behavior, Agency Costs And Ownership Structure. Journal of Financial Economics, 3(10), 305-360. https://doi.org/10.1177/0018726718812602

Khomsatun, S., \& Martani, D. (2015). Pengaruh Thin Capitalization dan Assets Mix Perusahaan Indeks Saham Syariah Indonesia (Issi) Terhadap Penghindaran Pajak. Simposium Nasional Akuntansi XVIII, 1-23.

Lestari, M., \& Sugiharto, T. (2007). Kinerja Bank Devisa Dan Bank Non Devisa Dan FaktorFaktor Yang Memengaruhinya. Proceeding PESAT. https://doi.org/10.3847/15383881/aab1f6

Maulana, M., Marwa, T., \& Wahyudi, T. (2018). The Effect of Transfer Pricing, Capital Intensity and Financial Distress on Tax Avoidance with Firm Size as Moderating Variables. Modern $\quad$ Economics, 11(1), 122-128. https://doi.org/10.31521/modecon.v11(2018)-20

Puspita, D., \& Febrianti, M. (2018). Faktor-faktor yang memengaruhi penghindaran pajak pada perusahaan manufaktur di bursa efek Indonesia. Jurnal Bisnis Dan Akuntansi, 19(1), 3846. https://doi.org/10.34208/jba.v19i1.63

Richardson, G., \& Lanis, R. (2007). Determinants of the variability in corporate effective tax rates and tax reform: Evidence from Australia. Journal of Accounting and Public Policy. https://doi.org/10.1016/j.jaccpubpol.2007.10.003

Ross, S. (1973). Ross_1973_The economic theory of agency.pdf. In Msnbc.

Sugiyarti, S. M. P. L. (2017). Pengaruh Intensitas Aset Tetap, Pertumbuhan Penjualan Dan Koneksi Politik Terhadap Tax Avoidance (Studi Kasus Pada Perusahaan Manufaktur Yang Terdaftar Di Bursa Efek Indonesia Tahun 2012-2016). Pengaruh Intensitas Aset Tetap, Pertumbuhan Penjualan Dan Koneksi Politik Terhadap Tax Avoidance (Studi Kasus Pada Perusahaan Manufaktur Yang Terdaftar Di Bursa Efek Indonesia Tahun 2012-2016), 5(3), 1625-1642. https://doi.org/10.17509/jrak.v5i3.9225

Tambunan, M. E., Siregar, H., Manurung, A. H., \& Priyarsono, D. S. (2016). Determinan Intensitas Transaksi Afiliasi Pada Perusahaan-Perusahaan Dalam Group Bisnis di Bursa Efek Indonesia. Jurnal Manajemen Teknologi, 15(2), 121-138. https://doi.org/10.12695/jmt.2016.15.2.2

Taylor, G., \& Richardson, G. (2013). The determinants of thinly capitalized tax avoidance structures: Evidence from Australian firms. Journal of International Accounting, Auditing and Taxation. https://doi.org/10.1016/j.intaccaudtax.2013.02.005

Utama, C. A. (2015). Penentu Besaran Transaksi Pihak Berelasi: Tata Kelola, Tingkat Pengungkapan, Dan Struktur Kepemilikan. Jurnal Akuntansi Dan Keuangan Indonesia, 11(1), 37-54. https://doi.org/10.21002/jaki.2015.03

Wise, K. A., Naish, J. P., Dunn, A. W., Alty, D. G., Carr, B. R., \& Steeves, C. J. (2003). 
Corporate Tax Planning. Canadian Tax Journal.

Yuliana, I. F., \& Wahyudi, D. (2018). Likuiditas, Profitabilitas, Leverage, Ukuran Perusahaan, Capital Intensity dan Inventory Intensity Terhadap Agresivitas Pajak (Studi Empiris pada Perusahaan Manufaktur yang Terdaftar di Bursa Efek Indonesia Tahun 2013 - 2017). Journal of Chemical Information and Modeling, 53(9), 105-120.

Zain, M. (2007). Manajemen Pajak (Third Edition). Salemba Empat. 